\title{
Freight-Efficient Land Uses: Methodology, Strategies, and Tools
}

\author{
Jose Holguin-Veras ${ }^{1, * \mathbb{D}}$, Diana Ramirez-Rios ${ }^{1} \mathbb{D}$, Juvena $\mathrm{Ng}^{1}{ }^{\text {, Jeffrey Wojtowicz }}{ }^{1}$, Daniel Haake ${ }^{2}$, \\ Catherine T. Lawson ${ }^{3}$, Oriana Calderón ${ }^{1}$ (D) Benjamin Caron ${ }^{1}$ (D) and Cara Wang 4
}

1 VREF Center of Excellence for Sustainable Urban Freight Systems, Rensselaer Polytechnic Institute, Troy, NY 12180, USA; ramird3@rpi.edu (D.R.-R.); juvenang@gmail.com (J.N.); wojtoj@rpi.edu (J.W.); caldeo@rpi.edu (O.C.); caronb@rpi.edu (B.C.)

2 HDR Inc., Indianapolis, IN 46290, USA; Daniel.Haake@hdrinc.com

3 Department of Geography and Planning, University at Albany, Albany, NY 12222, USA; lawsonc@albany.edu

4 Department of Civil and Environmental Engineering, Rensselaer Polytechnic Institute, Troy, NY 12180, USA; wangx18@rpi.edu

* Correspondence: jhv@rpi.edu

\section{check for}

updates

Citation: Holguin-Veras, J.;

Ramirez-Rios, D.; Ng, J.; Wojtowicz, J.;

Haake, D.; Lawson, C.T.; Calderón,

O.; Caron, B.; Wang, C.

Freight-Efficient Land Uses:

Methodology, Strategies, and Tools.

Sustainability 2021, 13, 3059.

https://doi.org/10.3390/su13063059

Academic Editors:

Federico Martellozzo and Marc

A. Rosen

Received: 30 November 2020

Accepted: 1 March 2021

Published: 11 March 2021

Publisher's Note: MDPI stays neutral with regard to jurisdictional claims in published maps and institutional affiliations.

Copyright: (C) 2021 by the authors. Licensee MDPI, Basel, Switzerland. This article is an open access article distributed under the terms and conditions of the Creative Commons Attribution (CC BY) license (https:// creativecommons.org/licenses/by/ $4.0 /)$.

\begin{abstract}
Land-use planning and policymaking is central to how communities manage their economic activity and the social and environmental impacts these activities produce. Because of this central role, enhancing land-use practices to better incorporate the needs and impacts of freight activity has strong potential to improve the efficiency of their associated supply chains. This paper summarizes the key findings of the NCFRP 08-111 project on "Freight-Efficient Land Uses (FELUs)", probably the most comprehensive research project to date aimed at designing policy procedures to foster land-uses that minimize the private and external costs associated with the production, transportation, and consumption of goods. As part of the paper, the authors define freight efficient land-uses, identify the principles that should guide the process towards FELUs, outline the process to develop FELU plans and programs, propose to analyze the freight efficiency of current and future land uses in their jurisdictions, and identify complementary initiatives (both land-use and transportation related) that could help mitigate the negative impacts on local communities. The authors discuss three illustrative cases that provide evidence on how land-use decisions produce unintended effects on local communities. The paper explains how decision makers can carefully consider the FELU principles in their planning and avoid or mitigate such negative results.
\end{abstract}

Keywords: freight efficiency; land use; urban planning

\section{Introduction}

Urban and metropolitan areas exist because they are efficient markets where goods and services are traded, individuals can find suitable employment opportunities, and companies can find the personnel they need. At the heart of these activities is the production and consumption of physical goods. Without a doubt, the vast majority of human and economic activities-including highly sophisticated service activities-utilize physical goods in one form or another. In this context, the ultimate goal of land-use planning in relation to freight activity should be to help achieve a seamless integration of freight activity into urban, suburban, and rural areas. Doing so would foster quality of life and livability, enhance economic competitiveness and efficiency, and reduce congestion and such related externalities as emissions, crashes, and conflicts with other road and sidewalk users.

Freight-Efficient Land Uses (FELUs) is a new concept defined by the authors as "the land-use patterns that minimize the social costs (private plus external costs) associated with both the supply chains and the economic activities that consume and produce goods, at all stages of production and consumption; including reverse and waste logistics." [1]. Achieving this goal, however, requires the implementation of land-use initiatives that seek to: 
1. Maximize the beneficial impacts associated with the production and consumption of physical goods, while mitigating or eliminating the externalities produced by the resulting freight traffic; and,

2. Recognize the dramatic effects of economic and technological trends-particularly, e-commerce and novel freight technologies-that are reshaping, and will continue to reshape, consumer behavior, transportation systems, land use, and the economy.

As implied in consideration (1), it is important to consider the production and consumption of goods separately from the freight traffic that is generated [2]. The reason is that freight generation - both freight production and attraction-is, in most cases, an inherently beneficial activity that increases economic welfare and wellbeing by making it possible for businesses and individuals to access needed supplies. Moreover, the places of production are often physically separated from the places of consumption, therefore, the physical transport of goods to consumption locations is required [3]. The resulting freight traffic - a byproduct of the economic transactions-produces negative externalities. Instead of curtailing freight traffic, which is bound to have negative impacts on the economy, the best approach is to use policies to maximize the benefits of the activities that produce and consume goods, while minimizing the negative externalities produced by the associated freight traffic [4].

Properly accounting for the effects of e-commerce and emergent technologies on consumer behavior, transportation systems, land use, and the economy-as suggested in consideration (2) - is imperative because their interactions determine the amount and nature of the freight activity. It suffices to say that the number of deliveries and shipments in the US, driven by e-commerce, has more than tripled since before e-commerce [5]. With the growth of e-commerce transactions, there is evidence of an increase in truck traffic entering the cities causing negative externalities, including congestion and pollution [6]. Notwithstanding the major changes already produced by e-commerce, all signs indicate that the speed of the transformation and the depth of the impacts produced by e-commerce will increase with the eventual deployment of such emergent vehicular technologies as autonomous freight vehicles, including delivery droids, drones, and others [1]. These trends have direct impacts on land use and transportation. The recent COVID-19 pandemic has made matters worse as e-commerce purchases skyrocketed. Recent studies have confirmed these increases in different parts of the world, where logistical decisions like stockpiling for e-commerce purchases affects the space requirements and location of establishments [7-10].

When formulating land-use planning and policy, it is critical to account for the possible impacts on supply chains and freight activity. Considering the impacts on local supply chains and small businesses is particularly important. The reason is simple: the vast majority of supply chains and the freight activity generated are primarily local, and are associated with serving the needs of businesses and households (the latter thanks to ecommerce). The freight-intensive sectors of the economy-those for which the production and consumption of supplies are a central element of their business activity-represent $45 \%$ of the number of establishments and about $49 \%$ of the employment in US metropolitan areas. The service-intensive sectors - where service activities are the core of the businessrepresent the rest. Thus, inefficiencies in supply chains directly impact about half of the US economy (the freight-intensive sectors), and indirectly impact the other half (the service-intensive sectors), because all sectors consume freight supplies.

One of the ways to quantify the impacts of supply chains and freight activity involves the use of trip generation models from NCHRP Report 37 "Using Commodity Flow Survey and Other Microdata to Estimate the Generation of Freight, Freight Trip Generation, and Service Trips: Guidebook" [2]. These estimates indicate the number of deliveries and shipments associated with commercial establishments, called business-to-business (B2B) trips. Using business-level publicly available data, such as the County Business Patterns data [11], the models are able to estimate the number of freight deliveries and shipments at the ZIP Code, county, city, MSA, and State levels. These estimates are available through the Freight and Service Trip Generation Software [12], one of the tools developed by 
the authors. While these estimates indicate the magnitude of freight vehicles generated at commercial areas, the business-to-consumer (B2C) trips, associated with e-commerce, provide the magnitude of freight traffic generated at the household levels. Together, $\mathrm{B} 2 \mathrm{~B}$ and B2C estimates are able to capture the magnitude of freight traffic at the different geographical areas.

In the typical American city, B2C represents 51\% of all deliveries and shipments, while B2B represents the remaining $49 \%$. In terms of the freight traffic generated, however, the story is different. The reasons for this difference are the number of vendors and carriers involved, and the spatial density of deliveries and pick-ups. The challenge in the case of $\mathrm{B} 2 \mathrm{C}$ is that there are no publicly available data that can be used to convert deliveries and shipments into freight trips. Complicating matters, the range of potential values in B2C is very large, ranging from one-such as a single delivery to a house in the suburbs- to as many as 100 deliveries or shipments per trip-such as multiple deliveries to a large building. Assuming that the average number of deliveries per route is equal to one for suburban locations, and between five and ten for dense urban areas, the $\mathrm{B} 2 \mathrm{C}$ share of the metropolitan traffic would be between $10 \%$ and $20 \%$ of the total. Acknowledging the freight impacts at the different geographical regions is critical for land-use planners and a necessary step towards a freight-efficient plan. Unfortunately, there are no established procedures to foster FELUs.

This paper summarizes the main concepts and principles for freight-efficient landuse (FELU) planning, the steps and elements to consider as part of a FELU plan, and the main findings as part of the project funded by the National Cooperative Highway Research Program (NCHRP), NCFRP 08-111 Project "Effective Decision-Making Methods for Freight-Efficient Land Use (FELU)" [13]. The latter is probably the most comprehensive investigation made to date on the development of the methodologies to foster Freight-Efficient Land Uses. This discusses the conceptual aspects of FELUs, how it can be translated into a FELU plan, and presents illustrative examples that motivate the need to incorporate FELUs into planning and policy.

The rest of this paper is organized as follows. Section 2 discusses relevant literature. Section 3 discusses three illustrative cases that provide important lessons about the importance of fostering FELUs. Section 4 defines the FELU concept and its principles. Section 5 summarizes the steps that land-use planners can follow to develop a FELU plan. Section 6 describes elements of FELU programs, or the set of actions aimed at fostering FELUs. Section 7 discusses key tools that decision makers can rely on to help develop FELU plans and programs. Finally, Section 8 summarizes the most salient findings and the corresponding policy implications.

\section{Literature Review}

The literature on freight-related land-use policy and planning is very sparse. If and when the topic of freight is mentioned, it tends to be in the context of the need to separate large traffic generators, such as manufacturing sites and distribution centers, from the rest of the urban and metropolitan fabrics. The existing literature rarely mentions the need of households and businesses for the supplies they need for consumption or further processing; or the necessity to use land-use policy and planning to mitigate the negative effects of supply chain activity.

However, a number of publications have raised alarm about the impacts of logistics sprawl on the sustainability of the supply chains, and the imperative necessity of integrating freight considerations into land-use policy and planning. Logistical sprawl refers to the tendency of periodically relocating logistics facilities to the outskirts of the city, which, as urban areas grow, results in longer truck travel distances from these facilities to city center [14]. Researchers have studied logistical sprawl in developed countries [14-23] and developing countries [24-26]. He, Shen [27] discusses some of these cases from a sustainability perspective. 
Studies in European cities provide evidence of logistics sprawl over nearly four decades. Dablanc and Rakotonarivo [14] studied the spatial changes of warehousing locations in the Paris region (the "Ile-de-France") during the period 1974-2008. Allen, Browne [15] analyzed 14 urban areas in the UK, and studied the relationship between facility location, logistics management, and urban form. Heitz and Dablanc [20] studied the Paris region and the Paris basin (megaregion) between 2000 and 2012 using a centrographic analysis. Todesco, Weidmann [23] analyzed the locations of logistics firms in Zurich during the period 1995-2012 and compared the average distance of the firms from the city center and analyzed the distribution of firms using distinct spatial typologies. Heitz, Dablanc [16] used warehouses' data for 2004 and 2012 in the "Ile-de-France" region and for 2007 and 2013 in Randstad, the Netherlands. Heitz, Dablanc [19] studied the location of logistics facilities in Gothenburg, Sweden, for the years 2000 and 2014, using two geographical levels of analysis, i.e., regional and metropolitan scales.

Studies in North America have studied the logistics sprawl at US metropolitan areas. Cidell [17] studied the dispersion of warehousing and trucking activity in the US between 1980 and 2005 using the Gini index. Dablanc, Ogilvie [21] studied Seattle and Los Angeles and computed the weighted geometric center of warehousing establishments between 1998 and 2009. Woudsma and Jakubicek [22] studied the logistics business and their employment levels for 2002 and 2012 in Canadian metropolitan areas, including Vancouver, Calgary, Montreal, Winnipeg, and Halifax. They found no evidence of sprawl for the smaller metropolitan areas (Winnipeg and Halifax). Kang [18] studied the largest 64 US metropolitan areas and found logistics sprawl between the years 2003 and 2013, and found that the distances between logistic facilities and their customers increased.

Logistical sprawl has also been found at metropolitan areas in developing regions. Gupta [25] studied the location of logistics facilities in the timber industry in the city of Delhi, India. Their findings suggest evidence of logistics sprawl in this particular industry at a rate of approximately $100 \mathrm{~m} /$ year for the past 25 years. Oliveira, Santos [24] found logistics sprawl in the Belo Horizonte, Brazil, and an average change of $1.2 \mathrm{~km}$ between 1995 and 2015. Moreover, in Brazil, Guerin and Vieira [26] analyzed the location of facilities in São Paulo between 2000 and 2017, with an average change in location of $1.8 \mathrm{~km}$.

Significant research has studied the spatial dynamics of logistics facilities in relation to the political boundaries, land-use and economic trends, and industrial development. Hesse [28] discusses two case studies in Berlin-Brandenburg, Germany, i.e., an integrated freight center and a dispersed logistics site, developed since the mid-1990s. The author analyzed the effects of land-use conflicts between the private and public sector that leads to further dispersion of the logistic activities. Debrie and Heitz [29] analyzed the spatial dynamics of logistics facilities of Paris and Montreal in response to the planning of public policies. Sakai, Kawamura [30] studied the spatial distribution of logistics facilities in light of the decentralization trend in the Tokyo Metropolitan Area. Their results reveal that the outward migration of logistics facilities during the period 2003 and 2013 had only a modest effect on shipment distances. Moreover, the study shows that truck efficiency improved during this period, mostly because the average load outweighed the slightly longer distances. Singh [31] studied the spatial patterns of warehouses in the Greater Toronto and Hamilton region in Canada, particularly for the periods before and after the 2008 recession. Their results show a slight growth of establishments after the recession, yet their spatial spread is not evident. Meza-Peralta, Gonzalez-Feliu [32] analyzed the logistics space of facilities in the city of Barranquilla, Colombia, as an example of the development of port cities in developing regions.

One of the chief challenges in land-use planning is managing the negative externalities produced by human activity. The Coase theorem, developed in 1960, proposes that the issue of negative externalities produced by firms could be handled optimally in the private market, as long as property rights—including the rights to land, noise, emissions-are clearly defined and there are no transaction costs [33]. Thus, firms can negotiate over the 
production of externalities in markets to reach the socially optimal levels without further governmental or institutional intervention.

However, this ideal market stands in contrast with the realities of land-use planning where property rights are difficult to define and quantify as in the case of pollution and noise, or where there are many stakeholders involved, such as in urban areas where externalities may affect broad communities Clinch, O'Neill [34]. Instead, planners may achieve what they call "impure Coasian solutions" where property rights are negotiated under regulatory and planning agencies [34]. Clinch, $\mathrm{O}^{\prime} \mathrm{Neill}$ [34] study how these solutions have been implemented in planning scenarios in Ireland by developing agencies to regulate rights to development. Shahab and Viallon [35] studied the case of Switzerland and showed how planning organizations can minimize transaction costs in the transfer of property rights.

A handful of worthy efforts have attempted to incorporate freight into land-use planning. At a national level, the United States has also approached the issues involving freight and land-use. The Federal Highway Administration released, in 2012, the freight and land-use handbook that provides a guide to government agencies, developers, building and streetscape designers, and freight carriers. This guide aims at properly assessing the conflicts that land-use decisions have on freight transportation. The guide suggests that appropriate and coordinated land-use policies that consider the impact on freight. Some of these include the creation of buffers around freight-intensive sites [36].

The National Cooperative Freight Research Program (NCFRP) Report 33, "Improving Freight System Performance in Metropolitan Areas: A Planning Guide", discusses how land use plays a key role in the freight efficiency. The report identifies a unique set of 54 initiatives to improve freight systems, categorized in eight major groups. A number of these initiatives are related to land use policy and planning. The first initiative considers the relocation of large traffic generators, which should be carefully considered due to the unintended negative effects that this initiative might produce. The second initiative is the integration of freight considerations in land-use planning processes [37].

The Ontario Ministry of Transportation's [38] freight-supportive guidelines are yet another example of efforts made to facilitate the integration of freight facilities into existing land-uses. The resulting Land-Use and Transportation Planning Guide discusses several strategies-for various combinations of scope, settlement size, setting, required resources, and land type. Some of these strategies include identifying areas for new freight facilities and freight-intensive land uses for future freight corridors. Their plan also protects the smaller scale freight movement, i.e., mail and courier services and deliveries to restaurants and retail establishments.

One of the most prominent cases is the logistic land-use plan enacted by the City of Paris, which is described in [39]. As part of the plan, the city of Paris reserved strategic areas close to the center to slow down logistics sprawl. More recently, they developed a new framework for urban logistics that consisted of larger multimodal sites. These multistory, mixed-use, and multimodal facilities allow these logistical activities to locate closer to the city center. An example of these facilities is the now-operational Chapelle International Logistics Hotel. This facility consists of a rail terminal, office buildings, and residential premises [40]. One of the key success factors of the Paris' logistics plan was their involvement with the public and private sectors [29], as the city of Paris created an operational charter with 80 partners and sixteen projects to improve logistics in the Paris region [39].

More recently, the National Cooperative Highway Research Program (NCHRP) funded one of the largest studies made for integrating freight and land-use planning. This important project entitled "Effective Decision-Making Methods for Freight-Efficient Land Use (FELU)" [13] developed methodologies to foster FELUs and introduces a set of tools and recommendations applicable to a wide variety of decision environments. The results of this project include, (i) a comprehensive guidebook for planners and policy decision makers [1]; (ii) an Initiative Selector, which is a web-based tool that helps select transporta- 
tion and land-use related solutions to specific problems; (iii) the Freight and Service Trip Generation Software (FASTGS) that estimates freight and service activity at a ZIP code and establishment-level for the entire United States, and (iv) a Behavioral Micro-Simulation (BMS) software that uses data to simulate freight and freight vehicles flowing through a metropolitan area. This paper explains the concepts and principles behind the project, more specifically, the concept of FELUs, which is a simple yet revolutionary concept that land use and transportation planners should consider in their decision making.

\section{Freight-Efficient Land Uses: Concept and Principles}

Land-use planning is essential to fostering quality of life and harmony among the myriad social and economic activities that take place and compete for space in urban and metropolitan areas. However, if not well thought out, land-use plans can detrimentally affect both private commercial supply chains and local communities. A land-use plan that, for instance, artificially increases the physical separation between the distribution centers that handle e-commerce deliveries and the intended receivers-households and commercial establishments - in the city center, will increase the vehicle-miles traveled (VMT) of the e-commerce traffic. This, in turn, will increase congestion, emissions, and accidents. In such cases, reducing the distance is likely to be socially beneficial, as it will reduce both the private costs and the externalities that affect local communities and the environment.

Research has shown that the private-sector objectives of supply chain efficiency and cost minimization align with the social objective of minimizing transportation externalities [41,42]. Increasing the efficiency of supply chains benefits the private sector while reducing these externalities. This alignment between private and social objectives is not a coincidence; it is a reflection of the profound interconnections between supply chains, the economy, and the externalities generated by freight activity. This insight is important for freight policy purposes as it implies that increasing the efficiency of freight activity are bound to generate considerable support from the freight transportation industry, leading to the proverbial and elusive win-win situations.

\subsection{The Concept of Freight-Efficient Land Uses}

To foster Freight-Efficient Land Uses (FELUs), it is important that an unambiguous definition of "efficiency" guides the overall process. As such, this definition is aspirational in nature, representing the goal to be strived for through the application of the principles and the development of decision-making tools over a reasonable period. Recognizing the need to consider the broad range of impacts that freight and supply chain activities have, the following definition is adopted:

"Freight-Efficient Land Uses (FELUs) are the land-use patterns that minimize the social costs (private plus external costs) associated with both the supply chains and the economic activities that consume and produce goods, at all stages of production and consumption; including reverse and waste logistics" [1].

The private costs involve all of the production/logistics/facility costs incurred by the business and infrastructure operators. Examples of private costs include labor, land, or buildings, equipment to operate the distribution center, and acquisition and operation of freight vehicles. The external costs, referred to as "externalities", are the impacts both positive and negative that affect those who are not directly involved in the economic activity performed, such as communities. Considering all externalities during the land-use policy process, even qualitatively, is what really matters. Examples of negative externalities are congestion, pollution, noise, security, accidents, and aesthetic degradation produced by freight activities. There are important reasons to consider social costs, as not doing so can lead to land-use patterns that generate significant externalities that negatively impact local communities, or that excessively penalize private-sector activity, to the detriment of the local economy. 
Considering the impacts on "all stages of supply chains" is important because of the interconnected nature of supply chain stages. A land-use planning decision that affects the location of a single facility in a supply chain could have major repercussions on both the upstream and downstream stages, as well as on the surrounding communities. The importance of a broader consideration of the impacts implied in social costs is illustrated in Figure 1. The figure shows the case of a city with a major retail district in its urban core. The supplies needed by the retail district come from a regional distribution center outside the city, which delivers the supplies to an urban distribution center using large trucks. From there, the supplies are delivered to the retail locations using ten delivery vans. Assume that the locations A, B, and C correspond to the locations where warehouses and distribution centers are allowed to locate. To denote the degree of road congestion, a color gradient pattern from bright red in the areas close to the center (indicating high congestion) to light yellow in the outskirts of the city (minimal congestion) has been applied to the figure.

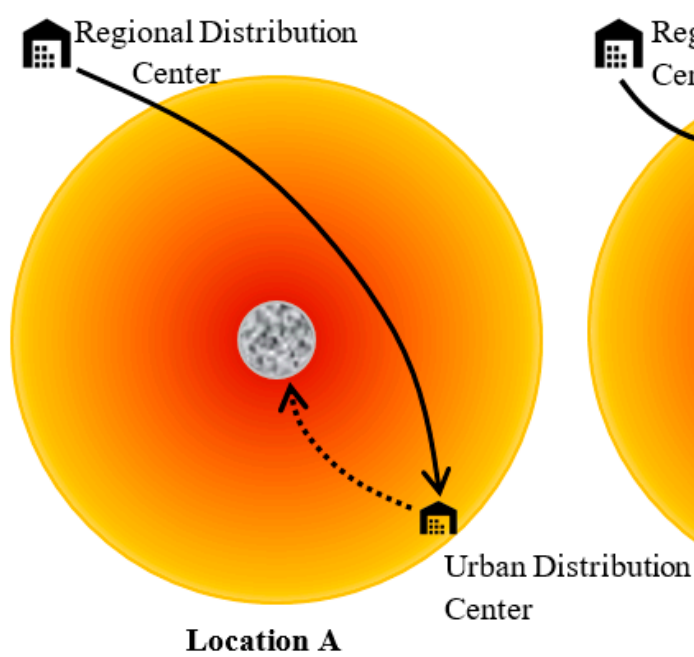

Location A

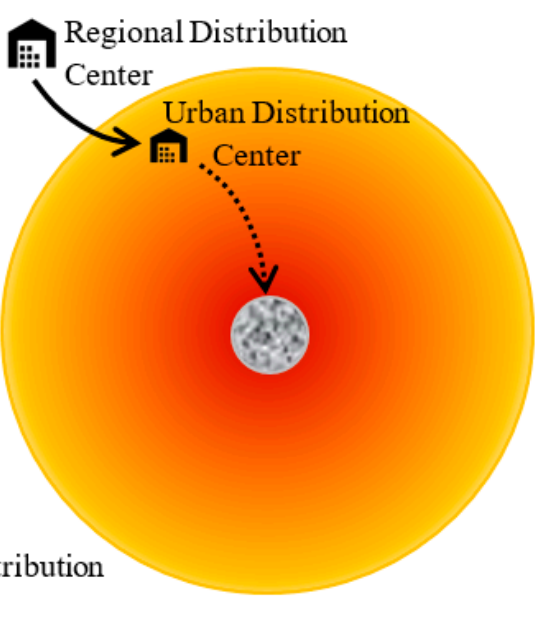

Location B

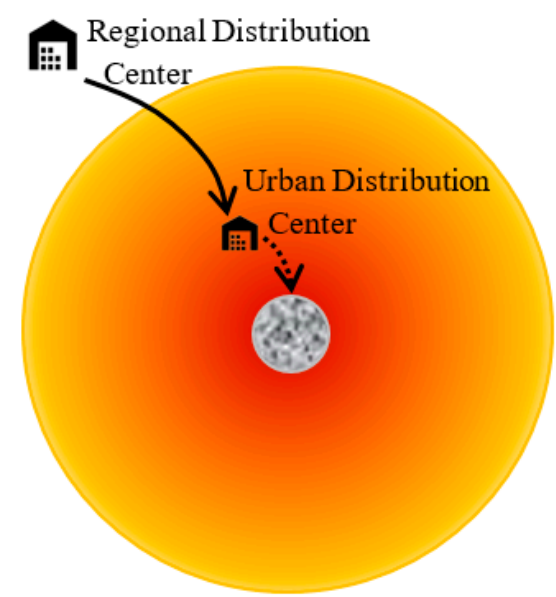

Location C

Figure 1. Effects of the Location of an Urban Distribution Center.

From the private-sector perspective, the only consideration is the private cost; in general, the externalities produced may not necessarily be considered. Thus, a distribution center will seek to be located where it maximizes its net revenue, which is the difference between its gross revenues and total logistics and facility costs. Since the cost of using a large truck is lower than the total costs of operating the multiple smaller delivery vans required to distribute the supplies (which depending on their size may be between five to fifteen delivery vans for every large truck), it is beneficial for the company to maximize the use of the large truck. At the same time, the company must consider the land costs, which generally increase with proximity to the urban core. Getting closer to the urban core only makes sense if the savings in transportation costs are larger than the increment in land costs. At the limit, the optimal location is the point at which the marginal savings in transportation costs is equal to the marginal increase in land cost. Among the three alternative locations, the best candidate is likely to be location $B$ if the land costs are comparable to those of location A. However, in both A and B, the delivery vans are bound to produce significant externalities as they travel to deliver supplies to their customers in the urban core.

In terms of the transportation-related externalities-emissions, accidents, road noise, and the like-and ignoring other externalities for the moment, location A is clearly the worst as it leads to long travel journeys for both the inbound supplies (regional distribution center to urban distribution center), as well as the delivery tours (urban distribution center to retail locations). Location B is certainly better, as it leads to a minimal inbound journey, though at the expense of creating relatively long trips by the small vans used to make deliveries to retail locations, thus, increasing VMT. Location C is likely to be the best among 
the three alternatives because it reduces the VMT produced by the outbound delivery vans by increasing the journey of the large trucks that supply the urban distribution center.

From the perspective of the impacts on communities near the urban distribution center, what matters are the externalities produced by the operation of the urban distribution center, such as conflicts with bicyclists, aesthetic degradation, emissions, and others. From this perspective, Locations A and B are the best because they would be located in areas with the lowest population density and traffic congestion. In contrast, Location C could be the most problematic because it would be located closer to the urban core, where congestion and population density are the highest. It is worth mentioning that the amount and extent of the impacts on communities are not the only consideration that matters. It is also important to consider how these impacts are distributed across the various population segments. It frequently happens that the negative effects of transportation activity disproportionally affect disadvantaged communities.

From the perspective of society, captured by the social costs, the optimal location depends on the private costs, the externalities produced (both positive and negative), and most importantly on whether or not the negative externalities could be mitigated or eliminated and the associated costs. If the negative externalities affecting the communities nearby location $C$, or if the remediation cost is too high, the location $C$ may not be optimal. In such a context and in the absence of remedial measures, the freight traffic at location $\mathrm{C}$ is bound to create externalities that provoke community opposition. However, there are numerous cases where the use of appropriate mitigating initiatives-such as context sensitive design, traffic management, buffer areas, and the use of environmentally friendly vehicles-could help reduce, or eliminate altogether, the negative effects, and location C could become the best choice.

\subsection{Freight-Efficient Land Use Principles}

The principles outlined in this section provide guidance for the formulation of FELU plans. Far from being prescriptive, one should interpret the FELU principles as guidance for action, to be adapted to the local conditions. These principles are: (1) Minimize Social Costs, to reduce the private and external costs of supply chains and their stages; (2) Foster Compactness of Supply Chains, to reduce the distance traveled at supply chain stages, up and downstream; (3) Mitigate Supply Chain Externalities, to reduce or eliminate, the externalities at supply chain nodes and Large Traffic Generators (LTGs); (4) Seek Appropriate Solutions, that recognize and account for local conditions; and (5) Engage Stakeholders, to ensure their points of view and concerns are addressed.

Principle (1) states the need to minimize the private and external effects produced by entire supply chains. This stands in contrast with the traditional focus of land-use policy, which centers on the impacts produced at a given site. In the case of land uses deemed incompatible with the rest of urban activities, the practice has been either to locate them in special districts, or to confine them to the outskirts of the urban area. However, in doing so, the subsequent impacts on the supply chains and the associated private and external costs are not considered. Achieving FELUs entails fostering compact supply chains, and reducing the private and external costs produced at the locations at the end of each supply chain stage.

Some of the most significant supply chain private and external effects are associated with the travel of freight vehicles at each stage of the supply chain. The longer the travel is, the higher the amount of private and external effects is. Principle (2) highlights the need to consider the impacts of land-use decisions on the distance traveled for both upstream and downstream supply chains. The consideration of the impacts of land-use decisions and the private and external costs associated with the travel between manufacturing locations to warehouses and distribution centers, from warehouses and distribution centers to retail locations and households, and the reverse and waste logistics, could lead to more compact supply chains, which could go a long way to fostering FELUs. 
Principle (3) stresses the need to mitigate the externalities caused by the freight traffic generated at supply chain nodes - retail locations, restaurants, warehouses and distribution centers, manufacturing sites, and LTGs in general-could produce major externalities that affect nearby communities and, naturally, generate community opposition. If these externalities are effectively mitigated it becomes easier to advance a FELU agenda.

Principle (4) recognizes the profound heterogeneity in land-use patterns and economic conditions in metropolitan areas and cities. This heterogeneity extends as well to their institutional and decision-making environments; each with their own land-use controls, comprehensive plans, and political environments. To complicate things further, each state has its own unique land-use enabling legislation and case law. Governance structures within a metropolitan area can be very diverse as well. Land-use control may be the responsibility of a city, county, village, or township. Considering these factors is key for the successful implementation of FELU plans.

Land-use planning decisions could influence a wide range of stakeholders in different ways. As a result, it is likely that these stakeholders will have different views on how land-use planning should advance community goals and objectives. Principle (5) states that it is critical to engage all stakeholders in a vibrant exercise of consensus building aimed at charting the path forward. This is particularly important when discussing decisions concerning the location of facilities that could negatively affect the surrounding communities. In these cases, it is imperative to involve all stakeholders in both the location decision, and the identification of remedial measures to mitigate or eliminate potential externalities.

\subsection{FELU Urban-to-Rural Transect}

As stated, the quest to achieve FELUs is one of integration, finding ways to seamlessly embed the freight activity generated by the local economy into the fabric of rural, suburban, and urban communities. To visualize this perspective, the authors build on the Transect concept to illustrate where the various freight-intensive sectors (FIS) and the supporting logistical activities should be located. To this effect, the authors created the FELU Transect.

Figure 2 shows, underneath the Transect zones, the: (1) typical (observed) locations of key FIS, households, and the service-intensive sectors as a whole, and (2) the suggested locations of the logistical facilities that serve these establishments. To facilitate interpretation, the various FIS - which represent a particular industry sector or group of industry sectors-have been sorted in descending order of the freight trip generation (FTG), while the logistic facilities have been sorted in descending order of size. In addition, a color gradient from dark green (high density) to light green (low density) has been added to the arrows to symbolize the density of establishments for a particular sector or group of sectors.

As suggested in the figure, the largest density of establishments typically takes place in city centers and the areas surrounding them. This is particularly the case for retail trade, accommodation and food services, service-intensive sectors, as well as residential locations (which must be considered because of household Internet purchases). This pattern of locations has major implications because of the importance of these sectors as generators of freight activity: retail trade is estimated to produce between $30 \%$ and $40 \%$ of the freight activity in metro areas, accommodation and food another $10 \%$ to $20 \%$, and service-intensive sectors another $5 \%$ to $10 \%$ of the commercial freight traffic. On top of these numbers, one must also consider Internet deliveries to households. The combined effects of high establishment densities at city centers and large FTGs lead to a situation where freight activity reaches its highest values at, or near, city centers. City centers also happen to be the parts of metropolitan areas with the highest levels of congestion, and the most difficult access. To achieve FELUs, it is crucial to foster the development of urban distribution centers to reduce the physical separation between the sources of the supplies needed by these establishments, and the receivers. Doing so would reduce the freight VMT generated, leading to major reductions in the externalities that impact local communities. 
These urban distribution centers are bound to play an important role as the local hubs for Internet deliveries to households. 


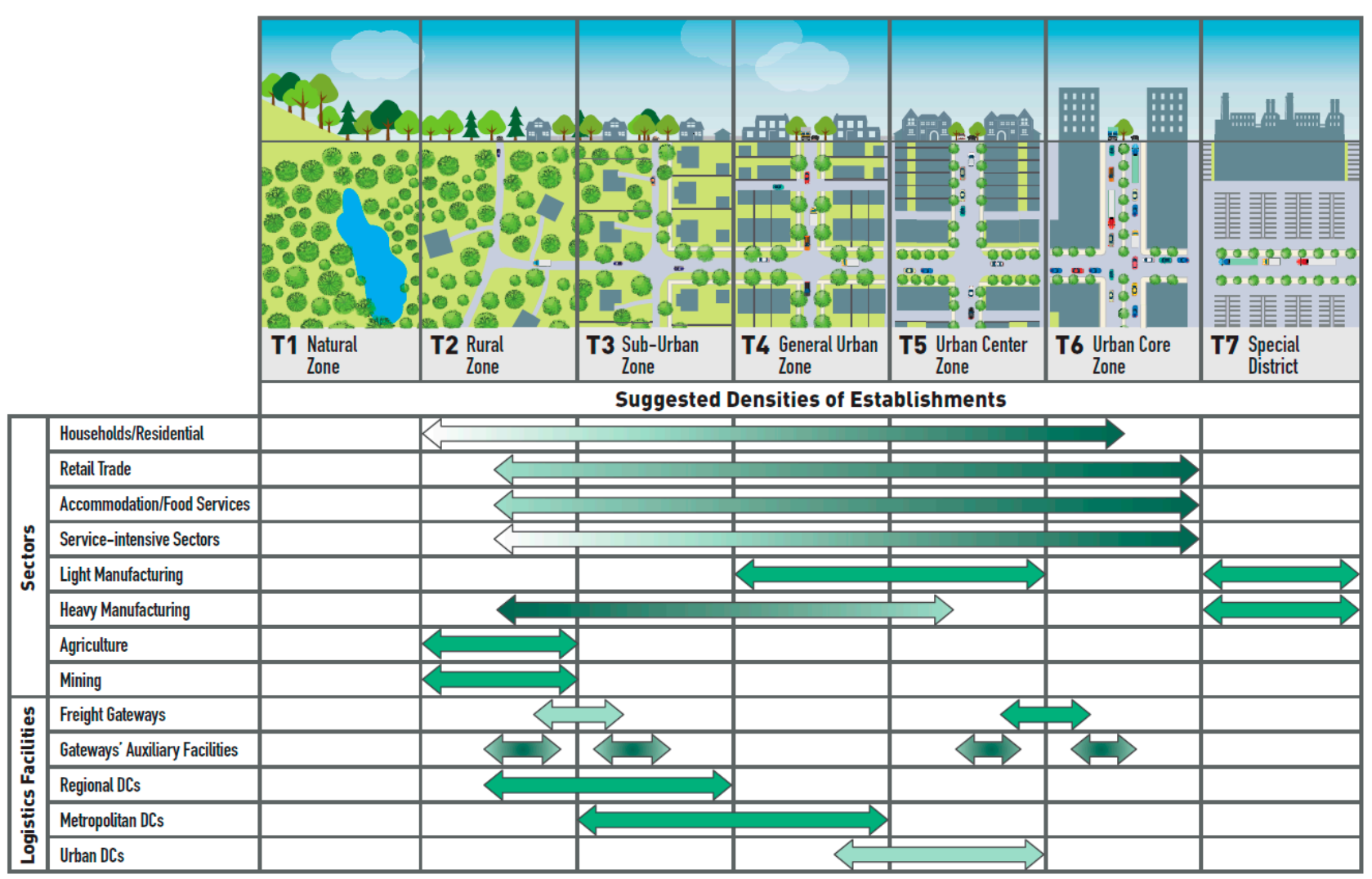

Figure 2. Freight-Efficient Land Uses (FELU) Urban-to-Rural Transect, Adapted From [43].

The next two largest generators of freight activity are light and heavy manufacturing. In terms of location, these exhibit different patterns. Heavy manufacturing-for historical reasons, regulations, or by necessity - tends to be close to major transportation facilities. In contrast, light manufacturing, by virtue of its smaller scale and lesser externalities, tends to be spread out in urban and metropolitan areas. Another important difference is related to the nature of the interconnection of manufacturing with other establishments. In the case of heavy manufacturing, these firms tend to rely on shipments from freight gateways, other large manufacturers, or regional distribution centers. In contrast, light manufacturing primarily deals with metropolitan distribution centers and large manufacturers in the region. As a result, it is not possible to treat manufacturing as a single homogenous group. While heavy manufacturing should be located near freight gateways, regional distribution centers, their local clients, and (obviously) the workforce; light manufacturing's ideal locations, from the standpoint of FELU, may be near metropolitan distribution centers, other manufacturers, their local clients, and their employees.

\section{Development of a FELU Plan}

The overall process to develop a FELU plan is outlined in Figure 3. There are four steps intended to: (1) gain a solid understanding of the chief features of the local economy, freight activity, and supply chain patterns in the area; (2) develop an understanding of the issues to be addressed, and the opportunities that could be exploited; (3) identify the most effective FELU initiatives; and, (4) engage stakeholders to determine the way forward. As implied in the figure, stakeholder engagement is intended to permeate the entire process of developing the FELU plan. The following sections discuss each step of the plan. 


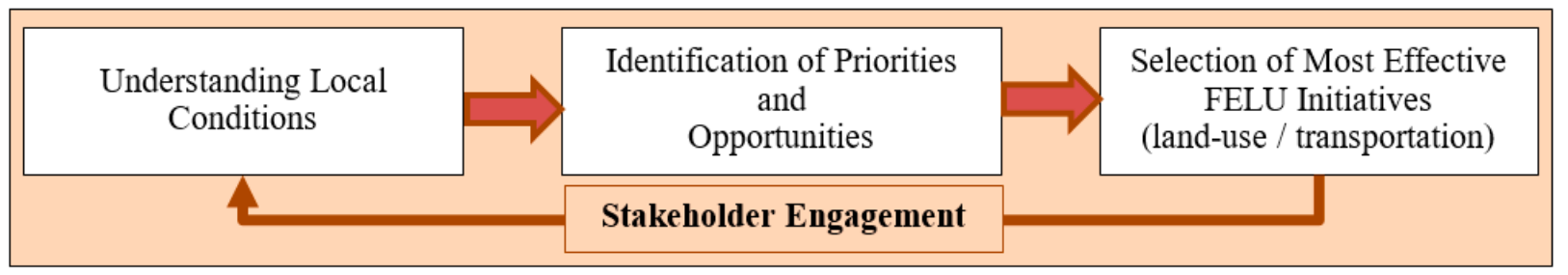

Figure 3. Steps to Produce a FELU Plan.

\subsection{Understanding Local Conditions}

The success of a FELU plan is based on a sound assessment of local conditions, in terms of: land-use patterns, and the geographic distribution of economic activities, particularly in the freight-intensive sectors of the economy; the associated supply chains and the resulting freight activity; as well as the issues identified as problematic by both communities and the private sector. Engaging the private sector is key to gaining qualitative knowledge about supply chain activity and the challenges that local supply chain stakeholders face. Gaining solid knowledge of local conditions is indispensable. These local conditions can change over time and the production of a FELU plan should consider further changes and be flexible to adapt to future local conditions. The FELU plan should also be flexible to adapt to disruptions, such as the COVID-19 pandemic. In this context, properties made vacant because of the economic slowdown can be used to repurpose in ways that foster FELUs, e.g., repurposing vacant retail space as mini-urban distribution centers.

Probably, one of the most important tools to gain insight into local conditions are freight trip generation (FTG) analyses. These relatively simply modeling efforts-which only require employment data by industry sector for the geographic areas of interestprovide crucial information about the industry sectors that generate the bulk of the freight traffic and, consequently, the sectors that ought to be engaged in finding solutions to the issues generated by their freight traffic. A comprehensive FTG analysis of selected US cities and metropolitan areas is found in [1].

\subsection{Identification of Priorities and Opportunities}

The development of a FELU plan should start with a clear identification of the freight issues to be addressed, which helps determine the priorities for action, and the opportunities that could be exploited on behalf of the community and the local economies. To a great extent, the identification of priorities will benefit directly from efforts to understand the local conditions. Starting with the identification of freight issues, the fundamental questions are: What are the most pressing freight issues impacting both local communities and the private sector? and, What could land-use planning and regulations do to help address the issues identified? Equally important is to identify any potential opportunities that could be involved, such as repurposing land that becomes available.

In this era of massive economic and technological transformations that could affect local communities in multiple, profound ways, it is important to consider the possible impacts these trends could produce at the local level. The main intent here is to ensure that land-use agencies are aware of not only the trends that could influence their jurisdictions, but also any potential opportunities that could be exploited for the benefit of the community. The joint identification of priorities for action and potential opportunities provides a solid platform for the next steps.

\subsection{Identification and Selection of FELU and Transportation Initiatives}

One key component of the NCFRP 08-111 project [13] was the development of a comprehensive list of initiatives that promote freight efficiency, to apply to both land use and transportation planning. These initiatives are essential to accomplish the objectives of the FELU Plan. The term "initiative" refers to an entire spectrum of mechanisms-projects, programs, regulations, and policies-that the public and private sectors can use to foster 
sustainable practices. Using complementary land-use initiatives, and complementary landuse and transportation initiatives, could be impactful because of the synergies between the initiatives. After an extensive literature review, discussion with academic experts and practitioners, and with public and private stakeholders, a set of 43 land-use and 61 transportation initiatives were identified. These initiatives cover a variety of decision areas that were categorized into eleven major groups: Facilities/Infrastructure Management; Parking/Loading Areas Management; Pricing, Incentives, and Taxation; Stakeholder Engagement; Long-term Planning; Zoning; Site/Building Design; Vehicle-related Strategies; Traffic Management; Logistical Management; and Freight Demand Management. A number of initiatives were labeled joint initiatives because they require the substantial involvement of both land-use and transportation agencies. Additional details about land-use initiatives, including one-page descriptions, are available in Holguín-Veras, Wang [1]. A schematic of the entire set of initiatives is shown in Figure 4.

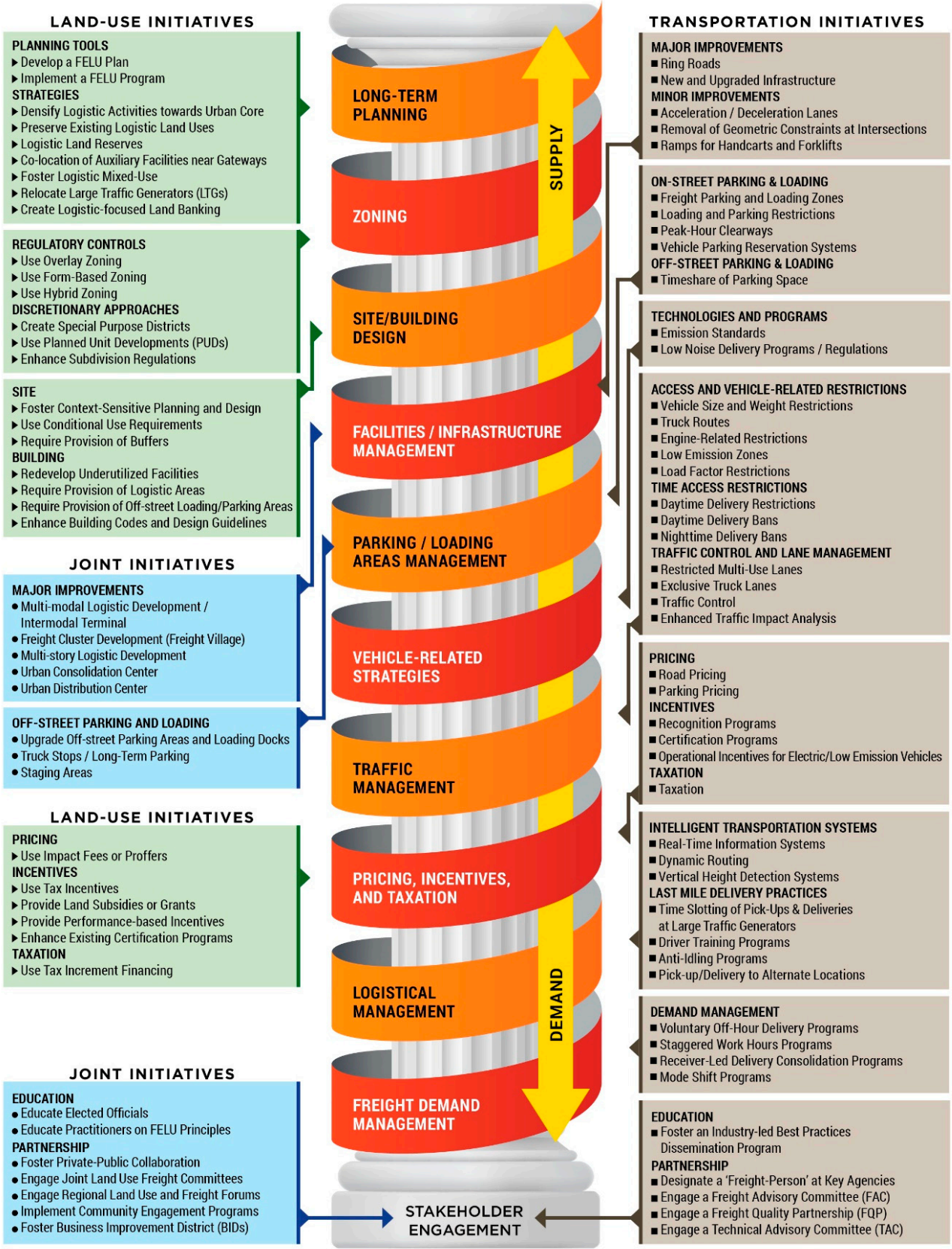

Figure 4. Land-Use and Transportation Initiatives. 


\subsection{Stakeholder Engagement}

Throughout the entire FELU process, is imperative to gain feedback and guidance from the various stakeholders affected by freight activity and the FELU initiatives that are implemented at any given stage. These stakeholders include policy makers, but also the participants in supply chains and freight activity and the community.

Traditionally, the transportation planning process has largely "integrated" freight stakeholders (shippers, carriers, receivers, and their representative associations) into its methods. Most notably, the FAST Act advocated state freight advisory committees [44]. However, transportation is only one-half of the equation to create freight-efficient landuse decisions. As freight transportation planning matured, the other half of the puzzle, land-use planning was largely left out of the conversation.

As a result, working to integrate freight stakeholders into the land-use planning process will be more complicated than transportation. The integration of freight stakeholders into the transportation planning process has largely happened at the metropolitan planning organizations (MPOs) and State Department of Transportation (DOT) levels. On the other hand, the land-use planning process takes place at the county and incorporated at municipality levels, which could pose tremendous challenges. In the United States, there are 50 State DOTs, 408 MPOs, and 19,354 "incorporated places". While each of the incorporated places might not have land-use controls, the difference in scale is clear. The inclusion of freight stakeholders in the land-use and transportation planning process(es) will be key to creating freight-efficient land-use decisions. A great deal of freight movement is driven by the location of freight shippers, distribution points, and receivers. With the rise of e-commerce, the "receiver" is often a residential building. Managing where freight "has to be" can decrease externalities on local communities and supply chains.

\section{Development of a FELU Program}

Land-use agencies can develop FELU Programs to list the initiatives needed to foster FELUs to increase the efficiency of supply chains and freight activity. In most cases, these actions and initiatives take place within the parameters previously set by a jurisdiction's long-term land-use plan. To help practitioners consider initiatives that foster FELU, the authors conducted a review of both land-use and freight practices and conceived potential initiatives based on extensive literature reviews, expert academic and practitioner knowledge, and discussions with public and private sector stakeholders.

To ensure a holistic treatment of how to address freight issues, a good place to start is the urban freight transportation decision-making process and the freight transportation initiatives identified in NCFRP Report 33 [37] and summarized in [45,46]. The freight transportation initiatives from NCFRP Report 33 were combined with newly developed land-use initiatives to form a comprehensive framework that can be used by both land-use and transportation agencies. As shown in Figure 4, the center pillar of achieving freightefficiency is based on the process of stakeholder engagement, without which implementing effective FELU initiatives is very difficult.

A FELU program is more effective when multiple initiatives work in combination to address different facets of the issue at hand. Such comprehensive use of FELU initiatives is bound to increase the efficiency of supply chains and foster the smooth integration of freight activity into the fabric of communities and the economy. As stated, this could be implemented through the use of complementary land-use initiatives or through the use of complementary land-use and transportation initiatives. For example, combinations of land-use initiatives are useful in certain cases so the resulting decisions do not create major transportation externalities that could provoke community opposition. Figure 5 shows an example of potential combinations of initiatives as a line connecting the initiatives from different groups. As shown in Figures 5 and 6, the land-use initiatives identified in the previous section have the potential to influence all facets and stages of land-use policy, planning, and decision-making. As a result, they offer great flexibility to address the diverse and complex freight issues that could arise from land-use decisions. The best outcomes are 
likely to arise from a judicious selection of both transportation and land-use initiatives that by, working together, help achieve the various objectives of the public sector intervention.

\begin{tabular}{|c|c|c|c|c|c|}
\hline $\begin{array}{l}\text { Planning and } \\
\text { Programming }\end{array}$ & Legal & Zoning & Site & Building & $\begin{array}{c}\text { Pricing, } \\
\text { Taxation, and } \\
\text { Incentives }\end{array}$ \\
\hline $\begin{array}{l}\text { - Do Nothing } \\
\text { FELU Plan } \\
\text { FELU Program } \\
\text { - Densify logistic } \\
\text { activities } \\
\text { - Preserve logistic } \\
\text { land use } \\
\text { - Preserve land } \\
\text { near logistical } \\
\text { facilities } \\
\text { - Foster Logistic } \\
\text { mix-use } \\
\text { - Relocate LTGs } \\
\text { - Land Banking }\end{array}$ & $\begin{array}{l}\text { Do Nothing } \\
\text { Building Codes } \\
\text { FELU supportive } \\
\text { guldelines for } \\
\text { design } \\
\text { PUDs } \\
\text { Enhance } \\
\text { subdivision } \\
\text { regulations }\end{array}$ & 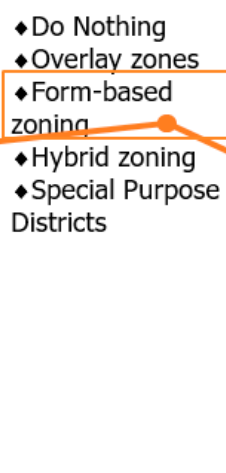 & $\begin{array}{l}\text { Do Nothing } \\
\text { Reuse under- } \\
\text { utilized facilities } \\
\text { Minimal size for } \\
\text { logistical areas } \\
\text { 2uffer zones, } \\
\text { setbacks, planting } \\
\text { strips } \\
\text { Physical access } \\
\text { requirements } \\
\text { Minimum off- } \\
\text { street } \\
\text { loading/parking } \\
\text { areas }\end{array}$ & $\begin{array}{l}\text { Do Nothing } \\
\text { Internal access } \\
\text { for hansiing cargo } \\
\text { Freight } \\
\text { elevators }\end{array}$ & $\begin{array}{l}\text { Do Nothing } \\
\text { Impact Fees } \\
\text { Tax incentives } \\
\text { Tax increment } \\
\text { financing } \\
\text { Land subsidies } \\
\text { Performance- } \\
\text { based incentives } \\
\text { Certification } \\
\text { programs }\end{array}$ \\
\hline
\end{tabular}

\section{Stakeholder Engagement}

Figure 5. Examples of Complementary Land-Use Initiatives.

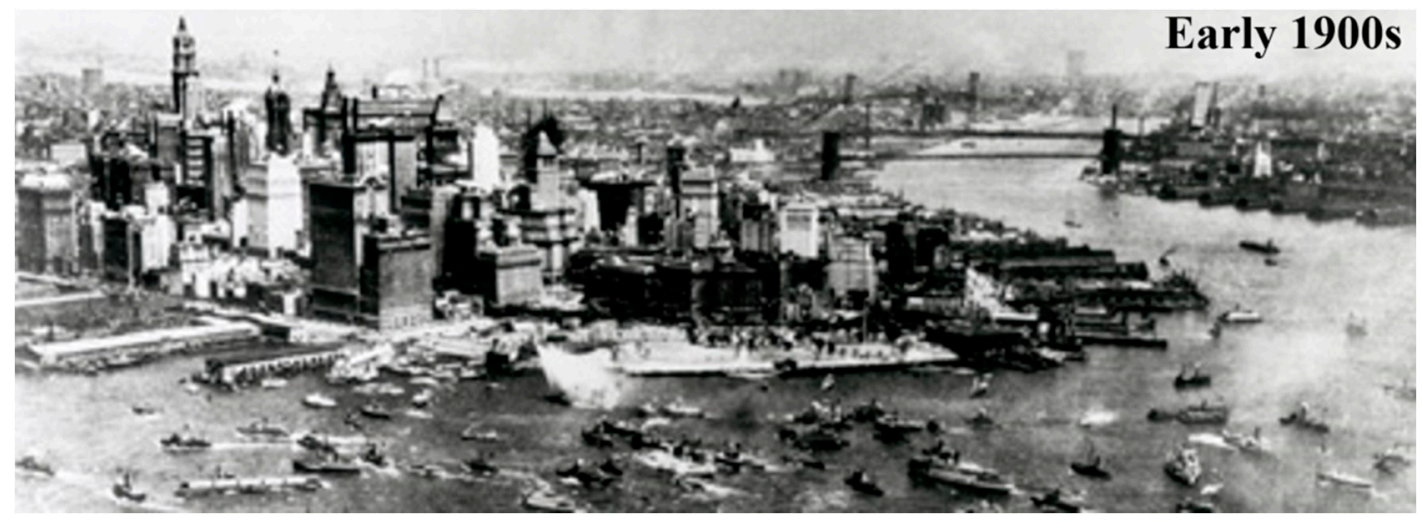

Figure 6. Port of New York and New Jersey in the Early 1900s, Adapted from [47].

The holistic use of land-use and transportation initiatives enables land-use planners to exploit the synergies and complementarities among initiatives, increasing the effectiveness of the entire effort. For instance, by using this holistic strategy, community concerns about the noise produced at an urban distribution center could be addressed by requiring the operator of the urban distribution center to use electric vehicles and low-noise equipment to bring supplies to the urban distribution center, and then use electric cargo bikes to make deliveries. Essentially, transportation initiatives assist FELU initiatives to facilitate the implementation of the land-use initiatives, creating a virtuous circle leading to FELUs.

\section{Illustrative Experiences}

This section discusses three real-life experiences that shed light on the importance of considering FELU principles. The intent here is to take, with the benefits of perfect hindsight, a retrospective look at land-use decisions that produce unintended effects on local communities that could have been avoided if proper consideration of the FELU principles had taken place. The first one is the relocation of the Port of New York, which was relocated from its original location in New York City to the other side of the Hudson 
River in the first half the 20th century. The second case is that of the city of Cali, Colombia, where three different municipal governments in the same metropolitan area implemented uncoordinated land-use policies in pursue of their own visions of growth. The last case focuses on the short-term impacts of the location of a distribution center in the Albany metropolitan area, and how the location decision impacted freight vehicle-miles-traveled.

\subsection{The Effects of Relocations of Large Traffic Generators: The Port of New York's Relocation}

The case of the Port of New York provides a compelling lesson about the importance of considering the effects of land-use decisions on the entire supply chain. In the early 20th century, the New York City (NYC) harbor was the biggest and most important port in the United States [48]. NYC's industrial sector grew due to its proximity to the port, and manufacturers crowded near the waterfront so that they could be near shippers [49]. Figure 6 shows the port in the early 1900s. By 1950, after the Port Authority took over the failing Port of Newark, maritime activities started to shift to the Port of Newark, which became the first port that could handle containerized cargo [47]. Over time, for reasons unrelated to the relocation of the port, the economic nature of NYC dramatically changed as its economic base evolved from manufacturing to a service orientation. This major economic shift did not mean that freight activity diminished. In fact, the opposite is true. At the height of its manufacturing heyday in the early 1960s, the 18.5 million residents and 8 million employees in the NYC metropolitan area generated about 2.8 million freighttrips per day (about 90\% by delivery vans and 6-tire trucks) [50]. As of 2016, the area's 20.2 million residents and 8 million employees generate about 5 million deliveries per day [51]. This includes about 2.0 million deliveries to commercial establishments, and about 3 million Internet deliveries to households. As the bulk of the freight being transported to NYC arrives at locations in Pennsylvania and New Jersey, the supplies must be transported across the Hudson River. The latter generates congestion on the bridges and tunnels, and costs NYC billions of dollars in congestion-over the past sixty years since the gradual relocation of maritime activity - to transport the cargo across the Hudson River.

This episode provides crucial lessons. The first is about the importance of considering the effects that a land-use decision concerning a specific freight node could have on the entire supply chains impacted by the decision. Although policymakers and communities in NYC most likely welcomed the move of the port-because of the removal of the associated freight traffic and the potential use of the vacated land for condominiums and residential buildings-very few could have foreseen the impacts that the subsequent transport of the cargo would produce across the congested river crossings. Undoing this decision has proven difficult and extremely expensive. The proposed Hudson River Freight Tunnel, intended to bring rail freight directly to NYC, is expected to cost between $\$ 7$ and $\$ 11$ billion $[52,53]$. Another important lesson is that the relocation of large traffic generators must be carefully thought out. The local benefits produced by such a move could be dwarfed by the externalities accrued over time in other parts of the urban area, reinforcing the need to use as a guiding principle the holistic concept of efficiency. In retrospect, retaining a meaningful portion of the port activity on the NYC side-though not necessarily in Manhattan-could have avoided the tremendous externalities brought about by the relocation of the port.

\subsection{The Effects of Lack of Coordination: Land-Use Policy in the Cali, Colombia, Metropolitan Area}

The Cali metropolitan area, located in the southwest of Colombia, encompasses five municipalities, though only three of them-City of Cali, with 2.5 million residents (2020); and Yumbo and Jamundí with 131,645 and 132,572 residents, respectively [54] —are relevant to the discussion. Of great import to this discussion are the physical constraints presented by the West Andes Mountains to the West, and the Cauca River and its flood plains to the East. Any growth in the Cali area would have to take place either to the North towards Yumbo, or to the South towards Jamundí. 
After the 1940s, the population of Cali almost doubled every ten years as Cali became highly industrialized. As a result, land values experienced large increases, which significantly impacted manufacturing, logistic activities, and residential development. In response to the increasing land costs, and the tax incentives offered by the city of Yumbo, manufacturers and logistic operators started to relocate from Cali to Yumbo. In the 1940s, Yumbo had around 100 small to medium industry establishments. By 2010, Yumbo had around 2000 companies, with 200 large multinationals [55]. The development in Yumbo, which centered around a narrow strip of land at both sides of the Pan-American Highway, led to a very inefficient use of the land where the only option for newcomers was to find land further north, along the highway.

At the same time, since the housing sector in Cali did not provide sufficient affordable housing to accommodate the population growth, people started moving south to Jamundí, seeking better options. This was made possible by the actions of Jamundís city leaders who saw urban development as the way to improve the city's finances. Thus, Jamundi's population grew from 44,438 inhabitants in 1985 to 132,572 in 2000 [54]. Further complicating matters, seeking to expand to accommodate the increasing population, numerous schools and universities located on the Cali-Jamundí corridor. The net result was the addition of tens of thousands of trips to the already congested corridor. The satellite pictures in Figure 7 show the development in the Cali metropolitan area between 1969 and 2016.
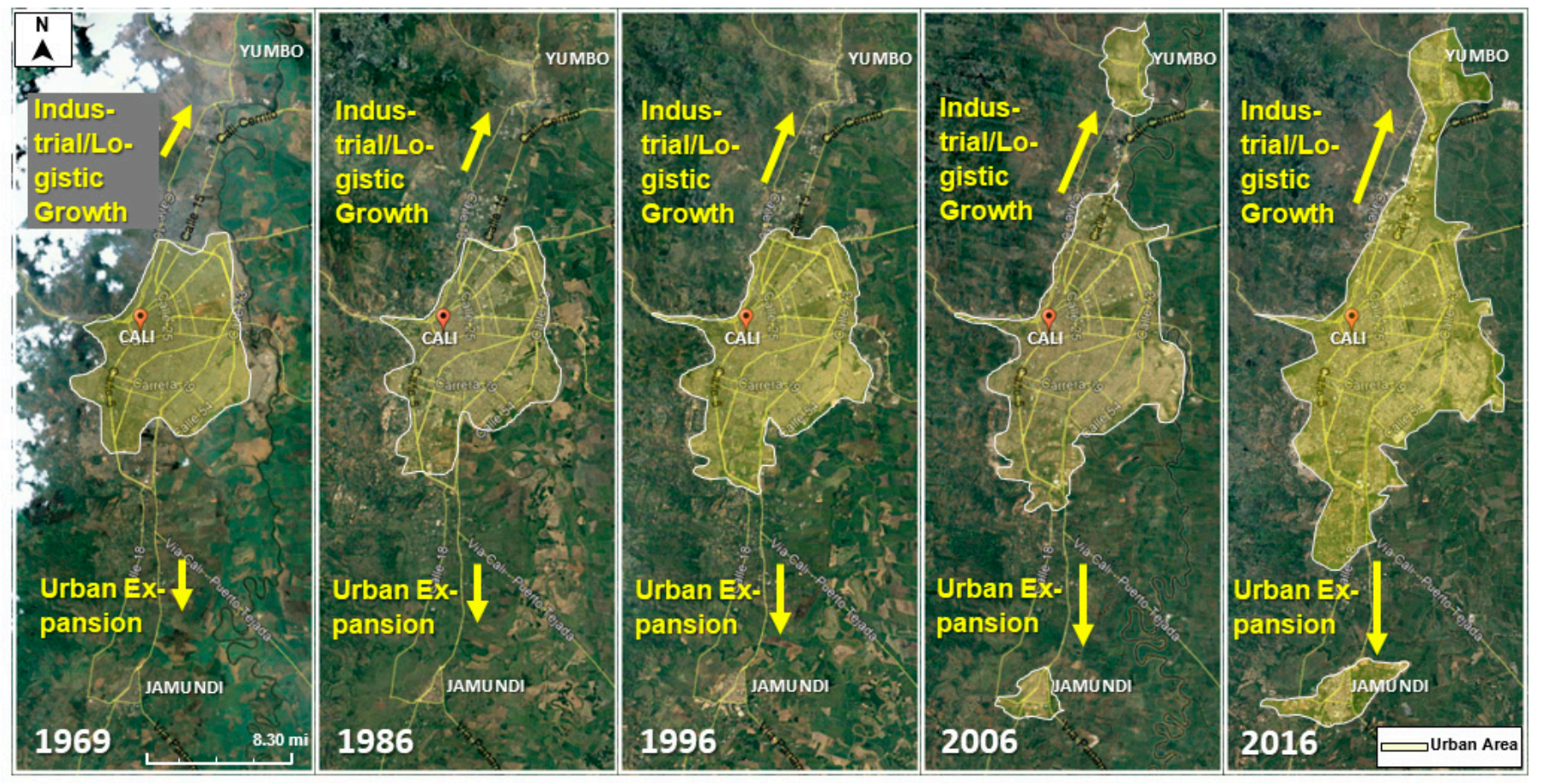

Figure 7. Expansion of Cali Towards Jamundí and Yumbo, Satellite Maps from Google Earth [56].

As people started moving south of Cali to Jamundí, and manufacturers and logistic operators kept expanding to Yumbo, Cali's congestion significantly worsened. The increased congestion was because of: (1) the commuter traffic from Jamundí to Yumbo during the peak traffic hours; (2) the traffic of trucks transporting the solid waste generated in the metropolitan region to a treatment facility located 27 miles north of Cali; and (3) the traffic of freight vehicles transporting supplies from Yumbo to Cali and Jamundí. Regarding the latter, Cali's officials have considered banning the freight thru traffic that, ironically, was created directly or indirectly by their predecessors' failures to implement a metropolitan vision for the Cali region. Had the City of Cali retained some manufacturing and logistic companies, Cali would have avoided some of the massive congestion created by the long journeys back and forth from Yumbo to the south of the metropolitan area. Moreover, some 
of that logistic capacity could have been used for last-mile deliveries to the urban core. Had the City of Yumbo conducted minimal land-use planning, it could have achieved its goal of becoming a manufacturing and logistical hub while using the land more efficiently.

\subsection{The Effects of Location of a Distribution Center: New York State Capital District}

The third case illustrates the effects of location of a distribution center in the Capital District, the metropolitan area of New York State's capital, Albany. Recently, a prominent Internet vendor decided to build an urban distribution center near Amsterdam, NY, with the explicit purpose of conducting last-mile Internet deliveries in the Albany metro area (about 37 miles between the distribution center and the center of the metro area). Originally, the vendor considered another facility in Colonie, NY, (about eight miles away from the center) and rejected the idea. Figure 8 maps the approximate locations of these alternative locations. Although it is likely that the retailer made this decision based on sound business considerations, the reality is that the decision adopted will lead to the creation of, at least, about 29 miles of travel for each one-way trip from the urban distribution center to the Albany metro area. This translates into a minimum of 800,000 freight VMT per year (assuming 100 freight trips a day, 275 days per year). Inducing the vendor to adopt the socially better location would have mitigated these externalities. This example shows the effects of considering, or not, the externalities produced by supply chains when selecting the location of a facility.

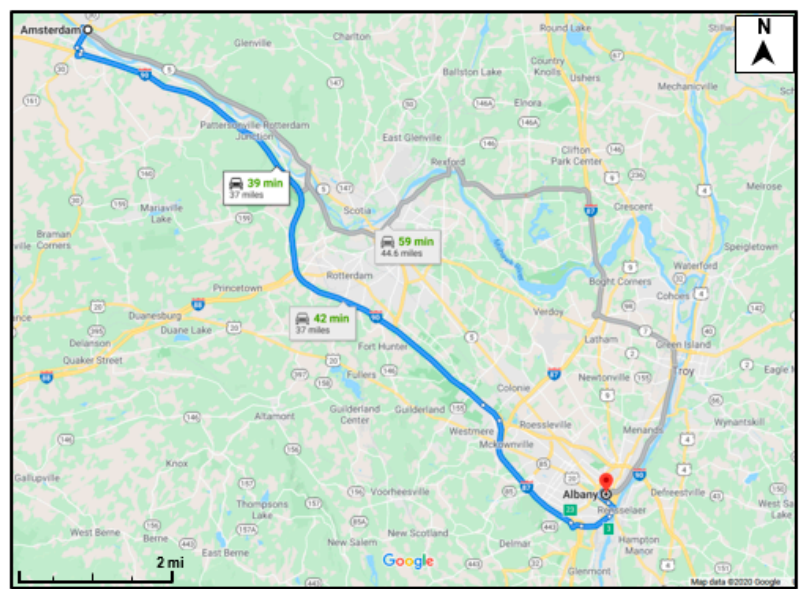

Pane A: Location Selected (Amsterdam, NY)

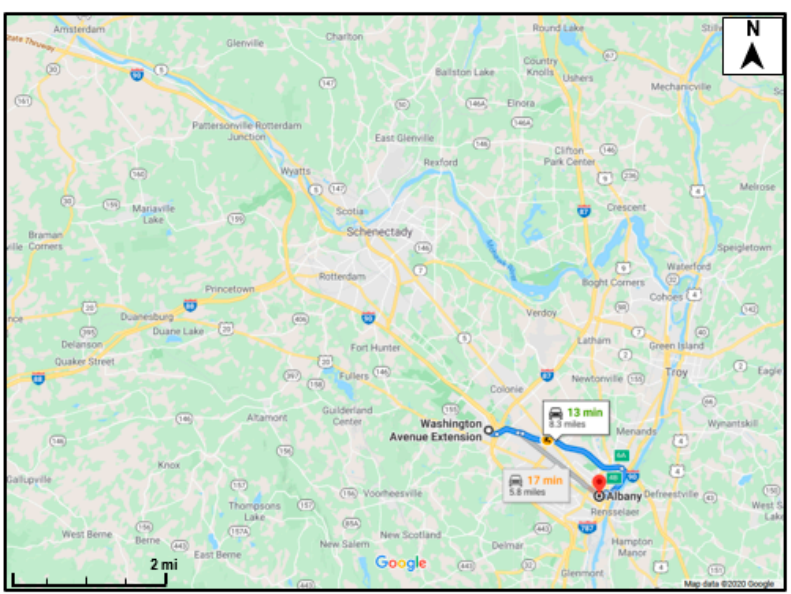

Pane B: Location Rejected (Colonie, NY)

Figure 8. Two Alternative Locations for an Urban Distribution Center in the Capital District, Google Maps [57,58].

This case provides a number of lessons. The first one is that private optimal location is not necessarily socially optimal. In this case, since the company seriously considered the Colonie location, it is likely that the provision of public sector incentives may have induced the company to locate there. This decision would place the DC closer to its customers and reduce operational costs and the associated externalities. However, for this to happen: (1) the relevant public sector agencies should play a proactive role in inducing FELUs; and (2) the private sector should be aware of these opportunities and be ready to engage the public sector. In the absence of (1), it is natural for the private sector to make decisions like the one selected by the vendor. There are other challenges to overcome. One of them is related to the financial implications on the municipal governments that eagerly seek to bring businesses to their jurisdictions in search of tax revenues and work opportunities for their residents. One possibility worthy of discussion may be the establishment of mechanisms of tax sharing among municipalities to compensate those negatively impacted by a FELU program. 


\section{Decision Support Tools That Foster FELUs}

As explained earlier, the NCHRP 08-111 project gave rise to a set of decision support tools (DSTs) that were developed and made publically available to assist decision makers in fostering FELUs. The decision support tools are qualitative and quantitative methods that provide conceptual depictions and ideas about general impacts and implications of land-use initiatives, and some of the numerical estimates needed for engineering and economic analyses. This combination of techniques is effective, flexible, and trustworthy. The products are designed to be straightforward so that they are understandable to a wide range of users. The decision support tools developed include:

- Guidebook for Planning Freight-Efficient Land Uses: Methodology, Strategies, and Tools: The main goal of this Planning Guide is to detail how practitioners could use the decision-making process and supporting tools to foster FELUs. This guide helps practitioners identify and weigh critical factors involved in the selection, design, and implementation of the selected FELU initiatives (strategies, programs, and projects). In addition, an electronic version of the Guide will be available that allows practitioners to navigate the Guide more easily and helps readers browse the sections that they are interested in.

- $\quad$ Land-Use and Transportation Initiative Selector: A dynamic webpage that, for a given set of inputs, provides practitioners with suggestions about potential initiatives to address land-use issues. This tool, which includes both land-use initiatives and the transportation initiatives from NCFRP Report 33, allows users to specify the problem they face, and obtain suggestions of potential solutions. Clicking on a suggestion produces a one-page summary that provides additional information about the initiative, to aid the user in considering its implementation. The Initiative Selector can be found at https:/ / cite.rpi.edu/iselector/ (accessed on 8 March 2021).

- Freight and Service Trip Generation Software (FASTGS): This tool estimates the generation of freight and service trips by commercial establishments. This uniquely important tool uses either employment data at the postal code, county, city, metropolitan statistical area (MSA), and State levels, which are publicly available, or employment data at the establishment-level provided by the user, to estimate the number of deliveries received and shipments sent out by commercial establishments. A basic version of this module is available at https:/ / cite.rpi.edu/index.php/software-and-tools / (accessed on 8 March 2021). (Registration required).

- Behavioral Micro-Simulation (BMS): This is a stand-alone software that enables practitioners to compute aggregate metrics of performance related to the impacts of land use on supply chain activity. The BMS reads freight trip data files (produced by the FASTGS), the travel times to and from the transportation analysis zones (including the location of distribution centers), the distribution of number of stops by industry sectors, and other input files to conduct a simulation of the supply chains operating in the area. The BMS produces a number of performance metrics that quantify the efficiency of the study area's supply chains.

\section{Concluding Remarks and Policy Recommendations}

Freight-Efficient Land Uses (FELUs) is a new concept defined as "the land-use patterns that minimize the social costs (private plus external costs) associated with both the supply chains and the economic activities that consume and produce goods, at all stages of production and consumption; including reverse and waste logistics" [1]. The concept by itself is simple and intuitive, but its implementation is not as straightforward. It builds on the impacts of economic activities that create supply chains and freight traffic. A solid knowledge of these interconnections will enable land-use planners and policymakers to be aware of the broader impacts of their decisions. Understanding the role played by the supply chains, the associated externalities, and the constructive role of land-use planning is key in fostering freight sustainability. 
A discussion of the literature provides ample evidence of the gap that exists in relation to the methodologies that foster freight-efficient land uses. The freight-related land-use policy and planning is very sparse. The freight research initially considered the separation of large traffic generators, like large distribution centers and production facilities, from the rest of the activities that reside at the core of the cities. However, the studies on logistics sprawl in past twenty years have turned matters around. The logistics sprawl research shows that periodically relocating logistic facilities at the outskirts of the city results in longer truck travel distances, making freight inefficient and detrimental for the consumers with respect to the externalities. To manage the negative externalities, other areas of research in the land-use planning side have considered ways to manage the negative externalities created by freight.

The literature also reported on the worthy attempts made to incorporate freight into land-use planning. These include the Freight and Land Use Handbook released by the Federal Highway Administration [36], the National Cooperative Freight Research Program (NCFRP) Report 33 [37], the Freight-Supportive guidelines developed by the Ontario Ministry of Transportation [38], and the logistic land-use plan enacted by the City of Paris [39]. The most recent of these efforts is the NCFRP 08-111 Project "Effective DecisionMaking Methods for Freight-Efficient Land Use (FELU)", developed by the authors and one that aims to provide the necessary tools that better improve land-use and transportation planning at a wide variety of agencies and regions in the United States. This project is probably the most comprehensive research project to date aimed at designing policy procedures to foster land-uses that minimize the private and external costs associated with the production, transportation, and consumption of goods.

This paper discusses the underlying concepts and principles that support FELU, explains its application in a FELU plan, and further provides illustrative cases that give a retrospective look at land-use decisions that produce unintended effects on local communities that could have been avoided if proper consideration of the FELU principles had taken place.

As part of the FELU plan, the authors identified the initial steps in developing freightefficient policies: understanding existing conditions, identifying existing concerns and potential opportunities, and finally, selecting the most effective freight efficient land-use (FELU) initiatives. As a result of the NCFRP 08-111 Project, the authors identified a wide range of initiatives that help decision-makers consider potential alternatives on both the supply and demand sides of freight transportation. There are ten major groups of initiatives that are classified as land-use initiatives, transportation initiatives, or joint initiatives, where the collaboration of both land-use and transportation agencies may be needed or advised.

This paper discussed three cases to outline the need for FELU decision-making. The first one goes back to the 1900s. It studies the relocation of the Port of New York that provides a compelling lesson about the importance of considering the effects of land-use decisions on the entire supply chain. The second case discusses the development of one of the largest metropolitan areas of Colombia, Cali. The study emphasizes on the expansion that the city underwent in the past eight years, in particular the manufacturing sector that expanded to other two regions at opposite direction of the city. The failure to implement the minimal land-use plan resulted in major congestion issues and truck inefficiencies that impeded them from becoming one of the largest manufacturing and logistical hubs in the country. The third case illustrated the relocation of a distribution center in two key locations of Albany, NY's metropolitan area. The case analyzed how different the decisions made from a private cost point of view are, to one that aims at the socially optimal. Yet, the authors argue that for these decision to occur: (1) the relevant public sector agencies should play a proactive role in inducing FELUs; and (2) the private sector should be aware of these opportunities and be ready to engage the public sector. Once again, this case calls for a proactive response of considering FELU in land-use decision-making.

This paper also provided a brief summary of the decision-support tools that are publicly available to foster FELUs. These include a Planning Guide to foster FELU planning, the 
Land-Use and Transportation Initiative Selector, the FASTGS, and the BMS. The Planning Guide further outlines how land-use stakeholders can make freight-efficient land-use decisions and provides details on each initiative. The Land-Use and Transportation Initiative Selector is an electronic database that allows users to specify the type of problem they need to solve and outputs initiatives that could be effective in addressing the specified issue. Selecting a given initiative leads the user to a one-page summary, complete with examples, references, and links to related initiatives. The FASTGS and BMS are tools that compute aggregate performance metrics needed to support the evaluation of initiatives designed to foster FELU. The FASTGS provides estimates of freight flows and commercial (freight and service) vehicle trips generated by businesses and uses the publicly available data to generate aggregate estimates at the ZIP Code, county, city, MSA, and State levels. The BMS produces a number of performance metrics that quantify the efficiency of the study area's supply chains, such as VMT and number of freight trip tours.

In considering the FELU concept and principles, the authors would like to highlight some important actions and recommendations for policymakers. These actions will lay the groundwork for land-use and transportation agencies to move forward with innovative and effective initiatives to help achieve goals such as reducing congestion, improving productivity, increasing sustainability, and enhancing livability in urban areas. The following actions are recommended:

- Integrate freight into land-use planning. Public agencies should consider how they could have a role in supporting freight activity through comprehensive land-use planning. Agencies can consider the extent to which their current land-use plan harms or helps the efficiency and sustainability of supply chains that are integral to the economic activity in their regions. Doing so would help minimize the externalities produced by freight traffic and maximize the efficiency of freight activity.

- Consider local conditions in the process of planning and designing freight initiatives. For effective land-use planning and policy design, it is important to recognize the heterogeneity in land-use patterns, economic conditions, and government structures between regions. Studying the existing features of local economies and their associated supply chains will help to identify any strengths and weaknesses. The resulting knowledge will assist policymakers in identifying suitable policies to ensure that freight activities take place in the most sustainable manner. In addition, engaging the private sector is key to gaining qualitative knowledge about supply chain activity and the challenges that local stakeholders face.

- Educate decision makers on FELU goal and objectives. Inform public and private sector decision makers on the importance of freight so that they do not put in place policies and/or projects that will negatively affect freight operations. In addition, decision-makers may benefit from knowledge on developing a FELU program, using decision support tools to gain insight into local conditions, and understanding a wide range of land-use and transportation initiatives. Dissemination of key findings and training programs can equip staff at transportation agencies and land-use agencies with the technical expertise needed to play a competent and effective role in the implementation of FELU initiatives.

- Communicate and collaborate with multiple stakeholders across disciplines. Implementing FELUs require a multidisciplinary approach to enhancing the sustainability of economic activity. Gathering feedback from stakeholders, or those involved in freight activity, can help identify potential opportunities and can lead to better outcomes. Stakeholders can provide key information on how best to achieve particular urban freight goals. Specific recommendations include the following: the designation of a "Freight-Person" at key agencies; the creation of a joint land-use and freight committees that also includes the participation of the private sector; and the implementation of Community Engagement Programs.

- Conduct ex-post evaluations on the performance of implemented initiatives. Complete an assessment of the overall performance of the implemented initiative by gauging 
the effectiveness of an initiative at addressing a particular freight issue and reviewing any negative consequences that resulted from the initiative. These evaluations will help decision makers (within the agency or other agencies) understand the effects, both good and bad, of freight initiatives that have been implemented in real life.

Taken together, the concepts and principles presented in this paper provide guidance to transportation and land-use professionals and researchers about the potentially transformative role that land-use policy could play in improving sustainability of supply chains, by means of fostering FELUs. Notwithstanding its importance, the work presented here should not be interpreted as rigid rules to be followed at all costs. Instead, the work should be treated as suggestions to be modified and improved to meet the local conditions, culture, and economy. After all, this paper is only a first step towards the implementation of FELUs.

Author Contributions: Conceptualization, J.H.-V., D.H., C.T.L., and C.W.; Methodology, J.H.-V., J.N., D.R.-R.; Software, D.R.-R.; Formal Analysis, J.H.-V., D.H., C.T.L., J.N.; Data Analysis, D.R.-R., J.N.; Writing-Original Draft Preparation, J.H.-V., D.H., C.T.L., O.C. and B.C.; Writing-Review \& Editing, J.H.-V., O.C. and B.C.; Visualization, Calderó, D.R.-R.; Supervision, J.N., J.W.; Project Administration, J.W., J.N.; Funding Acquisition, J.H.-V., D.H., C.T.L., and C.W. All authors have read and agreed to the published version of the manuscript. All authors have read and agreed to the published version of the manuscript.

Funding: The research reported in this paper was supported by the NCFRP 08-111 project entitled "Freight-Efficient Land Uses (FELUs)." Additional support was provided by the VREF Center of Excellence for Sustainable Urban Freight Systems (CoE-SUFS), and the Center for Infrastructure, Transportation, and the Environment at the Rensselaer Polytechnic Institute.

Institutional Review Board Statement: Not applicable.

Informed Consent Statement: Not applicable.

Data Availability Statement: No new data were created or analyzed in this study. Data sharing is not applicable to this article.

Acknowledgments: The support from National Cooperative Highway Research Program. (NCHRP) and the guidance provided by William C. Rogers are both acknowledged and appreciated.

Conflicts of Interest: The authors have no conflict of interest.

\section{References}

1. Holguín-Veras, J.; Wang, C.; Ng, J.; Ramírez-Ríos, D.; Wojtowicz, J.; Calderón-Quevedo, O.; Caron, B.; Rivera-González, C.; Pérez, S.; Schmid, J.; et al. Planning Freight-Efficient Land Uses: Methodology, Strategies, and Tools: Guidebook; NCHRP Project 08-111; Transportation Research Board: Washington, DC, USA, 2020.

2. Holguín-Veras, J.; Lawson, C.; Wang, C.; Jaller, M.; González-Calderón, C.; Campbell, S.; Kalahasthi, L.; Wojtowicz, J.; RamirezRios, D. Using Commodity Flow Survey and Other Microdata to Estimate the Generation of Freight, Freight Trip Generation, and Service Trips: Guidebook; NCFRP Report 37; Transportation Research Board: Washington, DC, USA, 2017.

3. Holguín-Veras, J.; Lawson, C.T.; Jaller, M.; Sanchez-Diaz, I.; Wojtowicz, J.M.; Campbell, S.; Levinson, H.; Powers, E.L.; Tavazzy, L. NCHRP Report 739/NCFRP Report 19: Freight Trip Generation and Land Use; NCHRP Report 739/NCFRP Report 19; Transportation Research Board: Washington, DC, USA, 2012; p. 165.

4. Holguín-Veras, J.; Amaya Leal, J.; Seruya, B.B. Urban Freight Policymaking: The Role of Qualitative and Quantitative Research. Transp. Policy 2017, 56, 75-85. [CrossRef]

5. Pew Research Center. Online Shopping and E-Commerce. Available online: http://www.pewinternet.org/2016/12/19/onlineshopping-and-e-commerce/ (accessed on 24 April 2017).

6. Jaller, M.; Pahwa, A. Evaluating the Environmental Impacts of Online Shopping: A Behavioral and Transportation Approach. Transp. Res. Part D 2020, 80, 1-15. [CrossRef]

7. The Wall Street Journal. Grocers Stockpile, Build 'Pandemic Pallets' Ahead of Winter. Available online: https:/ /www.wsj.com/ articles/grocers-stockpile-build-pandemic-pallets-ahead-of-winter-11601199000 (accessed on 3 January 2021).

8. Hao, N.; Wang, H.; Zhou, Q. The Impact of Online Grocery Shopping on Stockpile Behavior in Covid-19. China Agric. Econ. Rev. 2020, 12, 459-470. [CrossRef]

9. Vancic, A.; Parson, G.F.A. Changed Buying Behavior in the COVID-19 Pandemic: The Influence of Price Sensitivity and Perceived Quality; Kristianstad University: Kristianstad, Sweden, 2020. 
10. Eriksson, N.; Stenius, M. Changing Behavioral Patterns in Grocery Shopping in the Initial Phase of the Covid-19 Crisis-A Qualitative Study of News Articles. Open J. Bus. Manag. 2020, 8, 1946-1961. [CrossRef]

11. U.S. Census Bureau. County Business Patterns. 2016. Available online: https://www.census.gov/data/datasets/2016/econ/ cbp/2016-cbp.html (accessed on 20 December 2018).

12. Holguín-Veras, J.; Ramírez-Ríos, D.; Wojtowicz, J. Freight and Service Activity Trip Generation Software (FASTGS). Available online: http:/ /54.200.164.152/home (accessed on 30 July 2017).

13. Holguín-Veras, J.; Lawson, C. NCHRP 08-111: Effective Decision-Making Methods for Freight-Efficient Land Use; National Cooperative Highway Research Program: Washington, DC, USA, 2017.

14. Dablanc, L.; Rakotonarivo, D. The Impacts of Logistics Sprawl: How does the Location of Parcel Transport Terminals Affect the Energy Efficiency of Goods' Movements in Paris and What Can We Do about It? Procedia Soc. Behav. Sci. 2010, 2, $6087-6096$. [CrossRef]

15. Allen, J.; Browne, M.; Cherrett, T. Investigating Relationships Between Road Freight Transport, Facility Location, Logistics Management and Urban Form. J. Transp. Geogr. 2012, 24, 45-57. [CrossRef]

16. Heitz, A.; Dablanc, L.; Tavasszy, L.A. Logistics Sprawl in Monocentric and Polycentric Metropolitan Areas: The Cases of Paris, France, and the Randstad, the Netherlands. REGION 2017, 4, 93-107. [CrossRef]

17. Cidell, J. Concentration and Decentralization: The New Geography of Freight Distribution in US Metropolitan Areas. J. Transp. Geogr. 2010, 18, 363-371. [CrossRef]

18. Kang, S. Relative Logistics Sprawl: Measuring Changes in the Relative Distribution from Warehouses to Logistics Businesses and the General Population. J. Transp. Geogr. 2020, 83, 102636. [CrossRef]

19. Heitz, A.; Dablanc, L.; Olsson, J.; Sanchez-Diaz, I.; Woxenius, J. Spatial Patterns of Logistics Facilities in Gothenburg, Sweden. J. Transp. Geogr. 2020, 88, 102191. [CrossRef]

20. Heitz, A.; Dablanc, L. Logistics Spatial Patterns in Paris: The Rise of the Paris Basin as a Logistics Megaregion. Transp. Res. Rec. 2015, 2477, 76-84. [CrossRef]

21. Dablanc, L.; Ogilvie, S.; Goodchild, A. Logistics Sprawl: Differential Warehousing Development Patterns in Los Angeles, California, and Seattle, Washington. Transp. Res. Rec. 2014, 2410, 105-112. [CrossRef]

22. Woudsma, C.; Jakubicek, P. Logistics land use patterns in metropolitan Canada. J. Transp. Geogr. 2020, 88, 474-488. [CrossRef]

23. Todesco, P.; Weidmann, U.; Haefeli, U. Logistics Sprawl in the Region Zurich. In Proceedings of the 16th Swiss Transport Research Conference, Monte Verità, Ascona, Switzerland, 18-20 May 2016.

24. Oliveira, L.K.D.; Santos, O.R.D.; Oliveira, R.L.M.D.; Nóbrega, R.A.D.A. Is the Location of Warehouses Changing in the Belo Horizonte Metropolitan Area (Brazil)? A Logistics Sprawl Analysis in a Latin American Context. Urban Sci. 2018, 2, 43. [CrossRef]

25. Gupta, S. Logistics Sprawl in Timber Markets and its Impact on Freight Distribution Patterns in Metropolitan City of Delhi, India. Transp. Res. Procedia 2017, 25, 965-977. [CrossRef]

26. Guerin, L.; Vieira, J.G. Logistics Sprawl in São Paulo Metro Area. Proc. Hambg. Int. Conf. Logist. 2018, 26, 147-165.

27. He, M.; Shen, J.; Wu, X.; Luo, J. Logistics Space: A Literature Review from the Sustainability Perspective. Sustainability 2018, 10, 2815. [CrossRef]

28. Hesse, M. Land for Logistics: Locational Dynamics, Real Estate Markets and Political Regulation of Regional Distribution Complexes. Tijdschr. Econ. Soc. Geogr. 2004, 95, 162-173. [CrossRef]

29. Debrie, J.; Heitz, A. The Location of Logistics Activities in Metropolitan Areas as an Issue of Urban Planning: A Comparison of Paris and Montreal. In Proceedings of the 14th World Conference on Transport Research, Shanghai, China, 10-15 July 2016.

30. Sakai, T.; Kawamura, K.; Hyodo, T. Spatial Reorganization of Urban Logistics System and its Impacts: Case of Tokyo. J. Transp. Geogr. 2017, 60, 110-118. [CrossRef]

31. Singh, G. Logistics Sprawl: Spatial Patterns and Characteristics of New Warehousing Establishments in The Greater Toronto and Hamilton Area; University of Toronto: Toronto, ON, Canada, 2018.

32. Meza-Peralta, K.; Gonzalez-Feliu, J.; Montoya-Torres, J.; Palacios-Argüello, L. Defining and Characterizing Urban Logistics Spaces: Insights from a Port City and Generalization Issues. In Proceedings of the 8th International Conference on Information Systems, Logistics and Supply Chain, Austin, TX, USA, 22-24 April 2020.

33. Coase, R.H. The Problem of Social Cost. J. Law Econ. 1960, 3. [CrossRef]

34. Clinch, J.P.; O’Neill, E.; Russell, P. 'Pure' and 'Impure' Coasian Solutions in Planning. Town Plan. Rev. 2008, 79, 623-650. [CrossRef]

35. Shahab, S.; Viallon, F.X. Swiss Land Improvement Syndicates: 'Impure' Coasian Solutions? Plan. Theory 2020, 1-19. [CrossRef]

36. Federal Highway Administration. FHWA Freight and Land Use Handbook; FHWA-HOP-12-006; U.S. Department of Transportation: Washington, DC, USA, 2012.

37. Holguín-Veras, J.; Amaya-Leal, J.; Wojtowicz, J.; Jaller, M.; González-Calderón, C.; Sánchez-Díaz, I.; Wang, X.; Haake, D.; Rhodes, S.; Hodge, S.D.; et al. Improving Freight System Performance in Metropolitan Areas; NCFRP Report 33; Transportation Research Board: Washington, DC, USA, 2015; pp. 1-212.

38. Ontario Ministry of Transportation. Freight-Supportive Guidelines; Ontario Ministry of Transportation: Toronto, ON, Canada, 2016; pp. 1-194.

39. Dablanc, L.; Nicol, M. Logistics and Land Use Planning: The Example of Paris. Available online: https://coe-sufs.org/wordpress/ 2017/05/webinar-18/ (accessed on 9 March 2020). 
40. Liu, Z.; Dablanc, L. Chapelle International: A Logistics Hotel in Paris. 2017. Available online: https://citylab.soton.ac.uk/ presentations/Dablanc_MF_Seoul.pdf (accessed on 9 March 2020).

41. Quak, H.; De Koster, M.B.M. The Impacts of Time Access Restrictions and Vehicle Weight Restrictions on Food Retailers and the Environment. Eur. J. Transp. Infrastruct. Res. 2006, 6, 131-150.

42. Holguín-Veras, J.; Xu, N.; De Jong, G.; Maurer, H. An Experimental Economics Investigation of Shipper-Carrier Interactions on the Choice of Mode and Shipment Size in Freight Transport. Netw. Spat. Econ. 2011, 11, 509-532. [CrossRef]

43. Center for Applied Transect Studies. The Transect. Available online: https:/ / transect.org/transect.html (accessed on 11 March 2020$).$

44. United States Department of Transportation. The FAST Act: Freight Provisions. Available online: https://www.transportation. gov/fastact/freight-factsheet (accessed on 11 April 2016).

45. Holguín-Veras, J.; Amaya Leal, J.; Sánchez-Diaz, I.; Browne, M.; Wojtowicz, J. State of the Art and Practice of Urban Freight Management Part I: Infrastructure, Vehicle-Related, and Traffic Operations. Transp. Res. Part A Policy Pract. 2020, 137, 360-382. [CrossRef]

46. Holguín-Veras, J.; Amaya Leal, J.; Sanchez-Diaz, I.; Browne, M.; Wojtowicz, J. State of the Art and Practice of Urban Freight Management Part II: Financial Approaches, Logistics, and Demand Management. Transp. Res. Part A Policy Pract. 2020, 137, 383-410. [CrossRef]

47. Port Authority of New York and New Jersey. History of the PANYNJ. Available online: https://www.panynj.gov/port/en/ourport/history.html (accessed on 11 March 2020).

48. Lueck, T.J. New York Port Changes with Shifting Economy. The New York Times, 1 June 1986.

49. Boyd, A. The Once Great Port of New York. In The Engines of Our Ingenuity; Columbia University Press: New York, NY, USA, 2014.

50. Wood, R.T. Measuring Freight in the Tri-State Region. In The Urban Movement of Goods; OECD: Paris, France, 1970; pp. 61-82.

51. Holguín-Veras, J.; Ramirez-Rios, D.; Encarnacion, T.; González-Feliu, J.; Caspersen, E.; Rivera-Gonzalez, C.; González-Calderón, C.; Da Silva Lima, R. Metropolitan Economies and the Generation of Freight and Service Activity: An International Perspective. In Urban Logistics: Management, Policy and Innovation in a Rapidly Changing Environment; Browne, M., Behrends, S., Woxenius, J., Giuliano, G., Holguín-Veras, J., Eds.; Kogan Page Limited: London, UK, 2019; pp. 19-51.

52. U. S. Department of Transportation, Port Authority of New York \& New Jersey. Draft Environmental Impact Study for Cross Harbor Freight Program; U. S. Department of Transportation, Port Authority of New York \& New Jersey: New York, NY, USA, 2014.

53. U. S. Department of Transportation, New York City Economic Development Corporation. Draft Environmental Impact Study Cross Harbor Freight Movement Project; U.S. Department of Transportation, New York City Economic Development Corporation: New York, NY, USA, 2004; pp. 1-1019.

54. Departamento Administrativo Nacional de Estadística. Estimaciones de Población 1985-2005 y Proyecciones de Población 2005-2020 Total Municipal por Área. Municipal_area_1985-2020.xls. 2011. Available online: https://www.dane.gov.co/index. php/estadisticas-por-tema/demografia-y-poblacion/proyecciones-de-poblacion (accessed on 3 August 2020).

55. La Republica. Yumbo Será la Ciudad Industrial del País en 5 Años. Available online: https://www.larepublica.co/economia/ yumbo-sera-la-ciudad-industrial-del-pais-en-5-anos-2094401 (accessed on 12 March 2020).

56. Google Earth Pro 7.3.3.7786. Cali, Colombia. Available online: http:/ /www.earth.google.com (accessed on 13 March 2020).

57. Google Maps. Driving Directions from Amsterdam, NY to Albany, NY. Available online: https://www.google.com/maps/ dir / Amsterdam,+NY / Albany, +NY / @42.78566,-74.1073464,11z/data=!3m1!4b1!4m14!4m13!1m5!1m1!1s0x89de61b8fd99daa5: 0x6a02ce40019868bf!2m2!1d-74.190356!2d42.9377453!1m5!1m1!1s0x89de0a34cc4ffb4b:0xe1a16312a0e728c4!2m2!1d-73.7562317 !2d42.6525793!3e0 (accessed on 13 March 2020).

58. Google Maps. Driving Directions from Colonie, NY to Albany, NY. Available online: https://www.google.com/maps/dir/ Colonie, +NY / Albany,+NY /@42.7469394,-73.9025741,12z/data=!4m14!4m13!1m5!1m1!1s0x89de0b8158d26189:0xd70156b653 80e293!2m2!1d-73.8334554!2d42.7178558!1m5!1m1!1s0x89de0a34cc4ffb4b:0xe1a16312a0e728c4!2m2!1d-73.7562317!2d42.652579 3!3e0 (accessed on 13 March 2020). 